\title{
MICROBIALITE FORMATION IN SEAWATER OF INCREASED ALKALINITY, SATONDA CRATER LAKE, INDONESIA-REPLY
}

\author{
GERNOT ARP, ANDREAS REIMER, AND JOACHIM REITNER \\ Geowissenschaftliches Zentrum der Universität Göttingen, Abteilung Geobiologie, Goldschmidtstraße 3, D-37077 Göttingen, Germany \\ e-mail: garp@gwdg.de
}

\section{INTRODUCTION}

Our paper (Arp et al. 2003) revises previous studies of Kaźmierczak and Kempe (1990, 1992), Kempe and Kaźmierczak (1990a, 1990b, 1993), and Kempe et al. $(1996,1997)$ on Lake Satonda reefs with regard to biofilm calcification and microbialite formation. We confirm that the transfer of bottom waters of increased alkalinity (due to sulfate reduction) to shallow water layers (mixolimnion) principally can support or cause biofilm calcification and microbialite formation in shallow waters (as suggested by Kempe 1990). However, their two-stage model of microbialite formation in Lake Satonda, which claims that superficial in vivo permineralization of coccoid cyanobacterial colonies by high-Mg calcite is followed by internal fibrous aragonite growth due to anaerobic decay of the entombed colonies to form microstromatolites (Kaźmierczak and Kempe 1990) as well as Wetheredella-like structures (Kaźmierczak and Kempe 1992) is a theoretical construct without supporting evidence from data and observations from Satonda crater lake. Also, the comparison of Lake Satonda stromatolitelike encrustations on green algae with early Paleozoic stromatoporoids by Kaźmierczak and Kempe (1990) lacks—in our opinion—any supporting evidence.

In their discussion, Kaźmierczak and Kempe reiterate allegations seemingly supported by images and data. At a closer look, results obtained from inadequately treated samples (air drying, etching fractures, or cutting planes), a tendentious identification of coccoid structures, analytical failures (basic mineralogy from EDX measurements), and biased consideration of data (supersaturation) results in theoretical misconceptions of post-mortem calcification of degrading cyanobacterial colonies. Our positions and arguments follow.

\section{DEFINITION OF MICROBIALITE AND MISQUOTATIONS}

Kaźmierczak and Kempe misinterpret the term "microbialite" and disregard its definition. The term was introduced and defined by Burne and Moore (1987), not Kennard and James (1986): "Microbialites are organosedimentary deposits that have accreted as a result of a benthic microbial community trapping and binding detrital sediment and/or forming the locus of mineral precipitation" (Burne and Moore 1987, p. 241-242). "Forming the locus of precipitation" does not imply an active role of microbes (in the meaning of physiologically shifting chemical equilibria). This means that "tufa," which mineralizes "passively" largely due to external factors, is a "microbialite."

This passive role of biofilm communities is exactly what we propose for aragonitic parts of the Satonda microbialites: a biofilm mineralization due to external hydrochemical forcing. Therefore, our title is in full agreement with the content of our paper and the definition of "microbialite."

Further misquotations are also found in Kaźmierczak and Kempe's discussion. They state that a mode of $\mathrm{CaCO}_{3}$ precipitation inside the common mucilage sheaths (glycocalix) as proposed for Satonda has been noticed in other in vivo calcified cyanobacterial mats and biofilms and that "In at least some of these examples, organically controlled precipitation occurs in the mucilage forming granular submicron $\mathrm{CaCO}_{3}$, followed by abiotic precipitation of more crystalline forms, such as aragonite needles." For these statements, Kaźmierczak and Kempe cite Cohen et al. 1977 (however, the correct citation is Krumbein et al. 1977), Jørgensen et al. 1983, Fenchel and Kühl 2000, Kaźmierczak et al. 2001, Paerl et al. 2001, Dupraz and Reid 2001, and Kühl et al. 2003. We have read these papers word by word and note that none of the cited papers describe in any place granular submicron $\mathrm{CaCO}_{3}$ precipitation followed by the formation of fibrous aragonitic crusts within a cavity-like anaerobic microenvironment. The paper Jørgensen et al. (1983) does not even deal with carbonates at all.

\section{CALCIFICATION OF BENTHIC CYANOBACTERIAL MATS PRESENTLY LIVING IN THE LAKE}

Kaźmierczak and Kempe used air-dried samples for SEM and EDX investigation to prove in vivo permineralization of cyanobacterial biofilms. Surfaces of such samples contain artificially precipitated salts, including carbonates from the evaporated lake water. Consequently, the EDX spectrum figured by Kaźmierczak and Kempe (Fig. 1G, this comment) shows peaks of $\mathrm{Na}, \mathrm{K}, \mathrm{Cl}, \mathrm{Ca}$, and $\mathrm{Mg}$.

We have imitated the procedure of Kaźmierczak and Kempe and confirm by our own EDX analyses that these minute crystals on air-dried samples are chlorides, sulfates, and in some cases probably carbonates $(\mathrm{Ca}, \mathrm{Mg}$, but no associated $\mathrm{Cl}$ or $\mathrm{S}$; supplementary data, see Acknowledgments). These are artificial precipitates, because air-dried subsamples show these precipitates, whereas microtome sections of subsamples fixed by $\mathrm{pH}$-buffered $4 \%$ formol-containing filtrated lake water are free of them (Fig. 1A-C). None of the hardpart microtome sections (1993 and 1996) revealed a "strong permineralization with ultra-small grains of $\mathrm{Mg}$-calcite." The use of $\mathrm{pH}$ buffered fixatives is necessary to avoid artificial $\mathrm{CaCO}_{3}$ mineral dissolution or precipitation after sampling and disproves Kaźmierczak and Kempe's continuously reiterated scenario of a massive in vivo permineralization of cyanobacterial mats in Lake Satonda. Permineralization in Kaźmierczak and Kempe's samples is post-mortem, but artificial.

Natural $\mathrm{CaCO}_{3}$ clots, however, were found in biofilm sections of our adequately treated samples taken in June 1996 at less than $1 \mathrm{~m}$ water depth (reef tops; Arp et al. 2003, their fig. 12). Biofilm samples from greater depths do not contain these $\mathrm{CaCO}_{3}$ clots. We applied wavelength-dispersive electron microprobe analysis to polished sections of this material. None of the scattered carbonate clots in the reef surface biofilms of 1996 (samples from less than $1 \mathrm{~m}$ depth) showed a Mg-calcitic composition; all of them had low Mg and high $\mathrm{Sr}$ contents indicating aragonitic mineralogy (Arp et al. 2003, their table 2). One sample from 1993 (0.5 m depth; Arp et al. 2003, their fig. 8A) shows fibrous aragonite inside Cladophora cells. In all other samples from 1993 and 1996 we simply did not find any $\mathrm{CaCO}_{3}$ precipitates in reef-surface biofilms.

Published efforts of Kaźmierczak and Kempe to identify mineral phases are restricted to two EDX spectra and one single EDX mapping of $\mathrm{Mg}$ (Kempe and Kaźmierczak 1993) and a further EDX spectrum in their discussion. These EDX measurements show mixed area signals from co-occurring mineral phases, which do not permit the interpretation of elemental ratios (uncalibrated intensities) or mineral identification (Kaźmierczak and Kempe's fig. 1G). Therefore, without spatial element distributions and cor- 


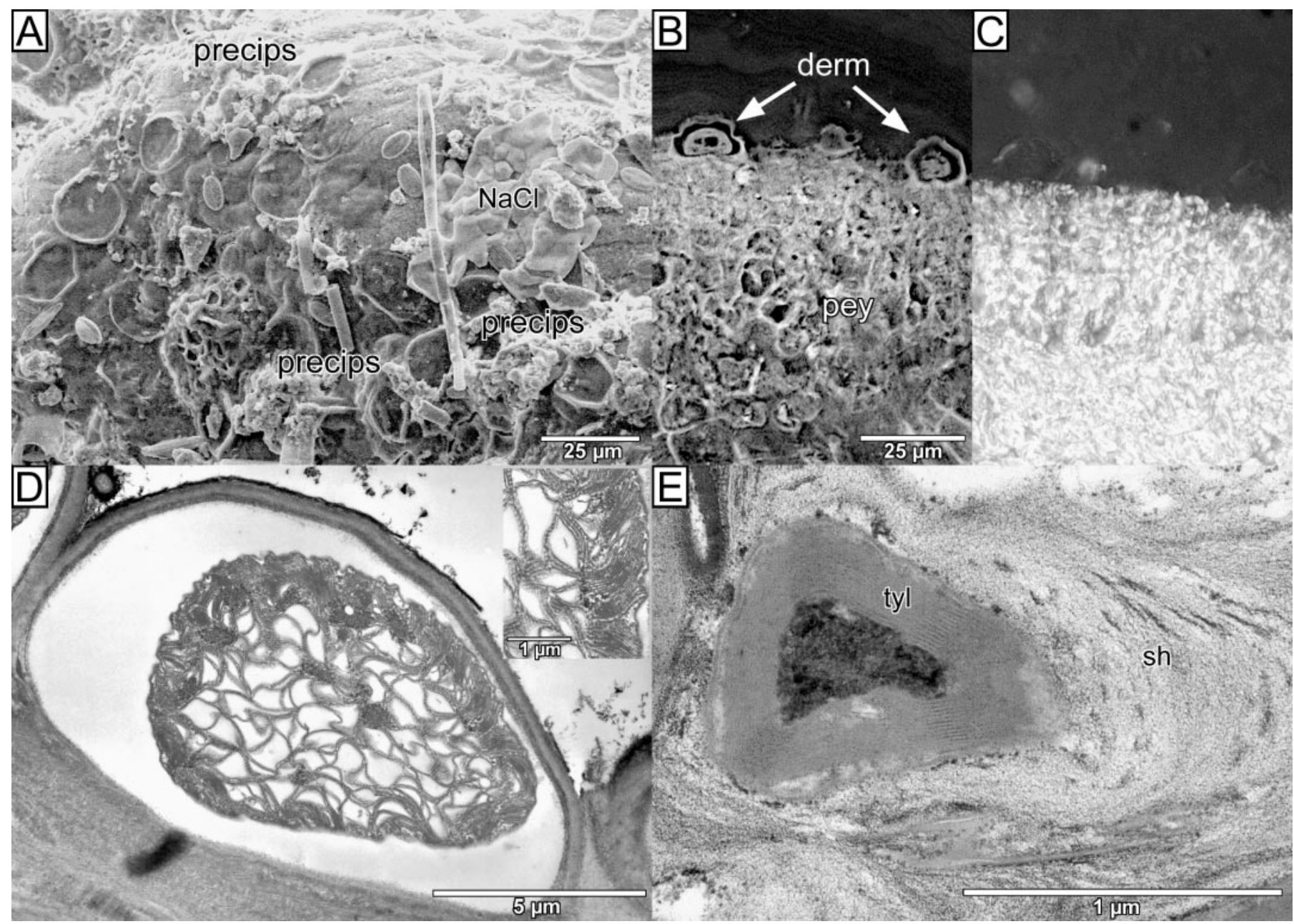

FIG. 1.-Artificial precipitates and identity of coccoid microorganisms, Satonda Crater Lake, Indonesia. A) SEM view of air-dried biofilm with spicule, diatoms, and collapsed cells on red algal reef surface. Note artificial precipitates of $\mathrm{NaCl}$ (hygroscopic) and other salts containing $\mathrm{Ca}^{2+}, \mathrm{Mg}^{2+}, \mathrm{Cl}^{-}$, and $\mathrm{SO}_{4}{ }^{2-}$. $14 \mathrm{~m} \mathrm{depth}$ reef \#10. Sample Sat 93/69.

B) Hardpart section of the same sample shown in part A. This subsample was fixed with $2 \%$ formol in $\mathrm{pH}$-buffered filtrated lake water. The epifluorescence micrograph shows hemispherical cells of the unicellular alga "Dermocarpella" (derm) upon red algal thallus (pey). C) Same view as in part B under crossed nicols, demonstrating that the biofilm including the unicellular algae is free of precipitates. For scale see part B. D) TEM section of hemispherical alga "Dermocarpella" showing a thick, stiff wall and thylakoids. Insert is a detail of thylakoid structure. $0.5 \mathrm{~m}$ depth, reef \#17 (TEM image 6372). Sample Sat 93/37.2. E) TEM section of a pleurocapsalean cyanobacterium with concentric parietal thylakoids and a layered sheath. $0.5 \mathrm{~m}$ depth, reef \#17 (TEM image 6395). Sample Sat 93/37.2.

relations or calibrated high-resolution point/line analysis of individual phases it is neither possible to conclude about the occurring mineral phases in their figure $1 \mathrm{~F}$ nor to state that any of the small mineral phases depicted in their figures $1 \mathrm{~A}$ to $1 \mathrm{~F}$ are $\mathrm{Mg}$-calcites.

Finally, even within one and the same paper, Kaźmierczak and Kempe have denoted their biofilm surface precipitates and the microcrystalline phase within the underlying subfossil crusts (i.e., the "microstromatolites") as both low-Mg calcite and high-Mg calcite (Kaźmierczak and Kempe 1990, low-Mg calcite on p. 1246-1247 and figure 4, "Mg-calcite" in figures 3B and C; Kempe and Kaźmierczak 1993, high-Mg calcite in text and figure captions, low-Mg calcite in Plate 8/2). This gave us the impression that Kaźmierczak and Kempe themselves were never sure about the mineralogy of these precipitates.

In summary, Kaźmierczak and Kempe never provided evidence of $\mathrm{Mg}$-calcitic permineralization of pleurocapsalean cyanobacterial biofilms in Satonda, neither with regard to mineralogy nor with regard to its existence.

\section{IDENTITY OF COCCOID MICROORGANISMS}

The procedure applied by Kaźmierczak and Kempe of air-drying biofilm samples also results in collapsed cellular structures. These collapsed structures were collectively assigned to coccoid cyanobacteria by Kaźmierczak and Kempe. However, in many cases we see only holes, which cannot be assigned to specific organisms (e.g., Kaźmierczak and Kempe discussion, their figure 1A). Among these (Kaźmierczak and Kempe, their figures 1BD), there are possibly also pleurocapsalean cyanobacteria because these 2 $10-\mu \mathrm{m}$-size coccoid cyanobacteria indeed occur in Lake Satonda reef-surface biofilms (Arp et al. 1999, 2003). Some collapsed "pleurocapsalean cyanobacteria"' shown by Kaźmierczak and Kempe (e.g., Kempe and Kaźmierczak 1993, their plates 6/4-6 and 7/1; Kaźmierczak and Kempe discussion, figure 1E) are similar to our unidentified alga "Dermocarpella" in size (12-15 $\mu \mathrm{m}$ diameter), shape (hemispherical), and occurrence as isolated cells, as demonstrated in Figure 1A-C. However, this alga has a stiff, layered wall and thylakoid arrangements (Fig. 1D) differing from 


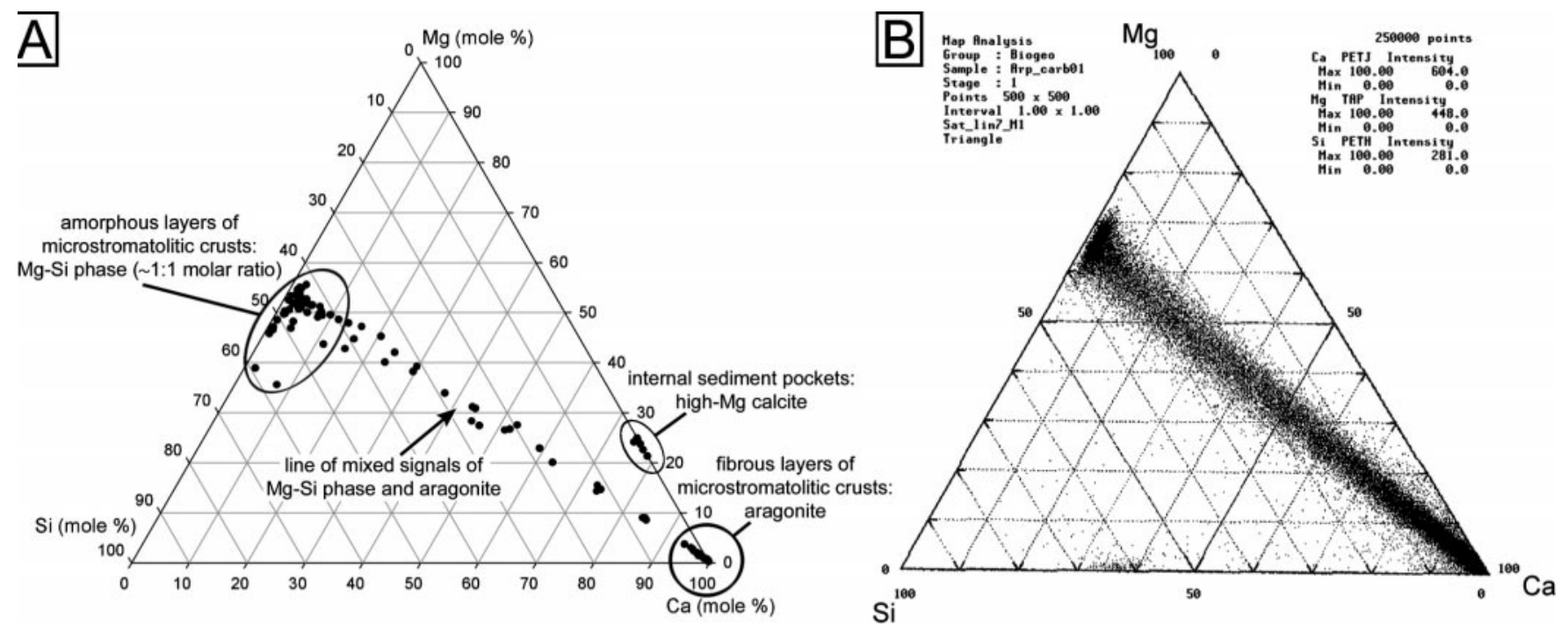

FIG. 2.-Electron microprobe analyses (WDX) of subfossil stromatolitic crusts, Satonda Crater Lake, Indonesia. A) Ternary plot of Ca, Mg, and $\mathrm{Si}$ (mole \%) compiled from four WDX traverses. Mixed signals obtained from thin dark layers of the microstromatolitic crusts plot between aragonite and the amorphous Mg-Si phase, whereas Mg-calcite of sediment pockets adjacent to the stromatolitic crusts forms a separate phase. Sample Sat 93/74 (1813). B) Ternary plot of Ca, Mg, and Si (uncorrected intensities) from an element map of a microstromatolitic crust. Note that there is no indication of Mg-calcite within the microstromatolitic crusts. Sample Sat 93/74 (1813).

pleurocapsalean and other cyanobacteria (Fig. 1E; see Stevens and Nierzwicki-Bauer 1991, Komárek and Čáslavská 1991, Chou and Huang 1991, Komárek 1999). Therefore, the systematic position of this alga remains unknown, and it is not clear whether this is a pleurocapsalean cyanobacterium at all.

For subfossil stromatolitic crusts, Kaźmierczak and Kempe presented etched cutting planes with holes (Kempe and Kaźmierczak 1993, their plate 8/4-5) and "coccoid" structures crosscutting the aragonite fibers (Kempe and Kaźmierczak 1993, their plate 8/2,6). The former are simply dissolution pits (no biogenic origin evident), but the latter are probably of endolithic origin. Because of the lack of biofilm sections, the presence of the endolithic cyanobacterium Hyella, which is abundant in shallow-water reef samples of Satonda, has not been noticed by Kaźmierczak and Kempe and is ignored continuously.

With regard to subfossil cyanobacterial remains, Kaźmierczak and Kempe show images of silicified cellular structures whose assignment to a certain organism group remains open to interpretation. Figures $2 \mathrm{C}$ and $\mathrm{E}$ of their discussion may show pleurocapsalean cyanobacteria-who knows? However, the spatial context remains unclear. Figures 2D and $\mathrm{F}$ of their comment show cellular remains within the cysts, which could be anything, also degraded sponge cells. No argument is presented by Kaźmierczak and Kempe to differentiate between epilithic and endolithic cyanobacterial cells and sponge cells. However, the subspherical wall indicated by the white and black arrows in their figures $2 \mathrm{D}, \mathrm{E}$, and $\mathrm{F}$ is of sponge origin, because of its well defined limitation, arch-like shape (note: cyanobacterial sheaths should encircle the colony cells), and composition (amorphous material, no $\mathrm{CaCO}_{3}$, neither aragonite nor high-Mg calcite).

In summary, there is no indication that cyanobacteria played a significant role in the formation of subfossil stromatolitic crusts in Satonda. Instead, an alternation of thin biofilm growth with upwelling of anoxic bottom waters during mixing events and growth of fibrous aragonite cement explains all observations and data (Arp et al. 2003).

\section{SUPERSATURATION IN 1986, 1993, AND 1996}

In their discussion, Kaźmierczak and Kempe state that in 1996 mixolimnion supersaturation was lower than in October 1993 and 1986 to explain why they viewed precipitates while we did not find them. This statement contradicts all hydrochemical measurements, including their own. (1) Supersaturation in shallow water near the lake shore $(0.1-0.2 \mathrm{~m}$ depth) remained virtually constant among the three years (Table 1). We emphasize that it was the uppermost meter at the end of the wet season in 1996 where we found the only $\mathrm{CaCO}_{3}$ precipitates in reef-surface biofilms. (2) The remaining parts of the mixolimnion, where we did not find calcifying reefsurface biofilms (1993 and 1996), show higher supersaturations compared to 1986 (Table 1). In their comment, Kaźmierczak and Kempe selectively exclude these facts.

Apart from that, the background supersaturation is not the crucial point because it reflects the metastable conditions of a water body due to nucleation inhibitors. Of central importance are ion fluxes, mass balance, and theoretical supersaturations during mixing events. We have demonstrated that the minor amount of $\mathrm{CaCO}_{3}$ found in the reef-top biofilms of 1996 is consistent with hydrochemical data (1993 and 1996) and mass-balance calculations. No such calculations were provided by Kaźmierczak and Kempe.

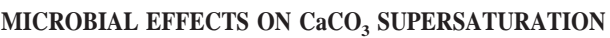

Kaźmierczak and Kempe state that " $\mathrm{CaCO}_{3}$ mineralization of cyanobacterial biofilms in Satonda Lake is not directly linked to their photosynthetic activity." We agree with this (Arp et al. 1999, 2003). However, later in their comment they state that " $\mathrm{CaCO}_{3}$ precipitation on the biofilm requires photosynthetic uptake of $\mathrm{CO}_{2}$ and / or $\mathrm{HCO}_{3}{ }^{-}$coupled with other environmental factors, like high $\mathrm{Ca}^{2+}, \mathrm{pH}$, and alkalinity levels" (in general and in Satonda). If we understand this statement correctly, they think that photosynthesis is one of several factors in Lake Satonda biofilm calcification (i.e., their supposed Mg-calcitic permineralization of cyanobacteria). If so, their statement is consistent with their publication in 1990, where they argue that the stromatolite samples (which in fact are subfossil aragonites!) show $\delta^{13} \mathrm{C}$ values approximately 5\%o more positive relative to the dissolved inorganic carbon (DIC) of the lake water in 1986 (Kempe and Kaźmierczak 1990b). From that, they concluded that "this is the typical fractionation for non-enzymatic $\mathrm{CaCO}_{3}$ precipitation with algae (e.g., Craig 1953)," "proving that the Satonda reefs are true stromatolites of cyanobacterial origin (Hofmann 1973; Walter 1983)"' (Kempe and Kaźmierczak 1990b, p. 308). Note that this violates their model of post-mortem anaerobic aragonite growth in cyanobacterial mats. 
TABLE 1.-Basic data on water chemistry of samples from the mixolimnion of Satonda Crater Lake.

\begin{tabular}{|c|c|c|c|c|c|c|c|c|c|c|c|c|c|c|c|c|c|}
\hline $\begin{array}{l}\text { Sampling } \\
\text { Period }\end{array}$ & $\begin{array}{l}\text { Depth } \\
\text { m }\end{array}$ & $\begin{array}{l}\mathrm{T} \\
{ }^{\circ} \mathrm{C}\end{array}$ & $\mathrm{pH}$ & $\mathrm{p} \varepsilon^{\mathrm{a}}$ & $\begin{array}{l}\text { Cond. } \\
\mathrm{mS} \mathrm{cm}^{-1}\end{array}$ & $\begin{array}{c}\text { Total } \\
\text { Alk } \\
\text { meq L-1 }\end{array}$ & $\begin{array}{c}\mathrm{DIC}^{\mathrm{c}} \\
\mathrm{mmol} \mathrm{L}^{-1}\end{array}$ & $\begin{array}{c}\mathrm{Na}^{+} \\
\mathrm{mmol} \mathrm{L}^{-1}\end{array}$ & $\begin{array}{c}\mathrm{K}^{+} \\
\mathrm{mmol} \mathrm{L}^{-1}\end{array}$ & $\begin{array}{c}\mathrm{Ca}^{2+} \\
\mathrm{mmol} \mathrm{L}^{-1}\end{array}$ & $\begin{array}{c}\mathrm{Mg}^{2+} \\
\mathrm{mmol} \mathrm{L}^{-1}\end{array}$ & $\begin{array}{c}\mathrm{SO}_{4}^{2-} \\
\mathrm{mmol} \mathrm{L}^{-1}\end{array}$ & $\begin{array}{c}\mathrm{Cl}^{-} \\
\text {Measured } \\
\text { mmol L-1 }\end{array}$ & $\begin{array}{c}\mathrm{Cl}^{-} \\
\text {Balanced } \\
\text { mmol L-1 }\end{array}$ & $\mathbf{S I}_{\mathrm{Cc}}{ }^{\mathrm{d}}$ & $\mathbf{S I}_{\text {Arag }}{ }^{\mathrm{d}}$ & $\begin{array}{c}\mathrm{pCO}_{2}{ }^{\mathrm{e}} \\
\mu \mathrm{atm}\end{array}$ \\
\hline \multirow[t]{4}{*}{ October 1983} & 0.1 & 31.8 & 8.50 & 6.67 & 42.7 & 3.72 & 3.11 & 409 & 11.6 & 5.59 & 40.7 & $18.0^{\mathrm{f}}$ & 478 & 478 & 1.00 & 0.86 & 324 \\
\hline & 2.0 & 29.9 & 8.43 & 6.84 & 38.8 & 3.60 & 3.10 & 410 & 11.4 & 5.39 & 44.5 & $18.0^{\mathrm{f}}$ & 479 & 487 & 0.90 & 0.76 & 380 \\
\hline & 10.0 & 29.8 & 8.42 & 5.55 & 38.8 & 3.68 & 3.18 & 409 & 11.4 & 5.54 & 43.4 & $18.0^{\mathrm{f}}$ & 479 & 484 & 0.92 & 0.78 & 398 \\
\hline & 20.0 & 28.6 & 8.33 & 5.67 & 38.5 & 3.60 & 3.21 & 405 & 11.3 & 5.39 & 43.2 & $18.0^{\mathrm{f}}$ & 475 & 479 & 0.82 & 0.68 & 513 \\
\hline \multirow[t]{5}{*}{ October 1993} & 0.1 & 30.7 & 8.58 & 4.52 & 38.9 & 4.17 & 3.42 & 420 & 11.5 & 4.69 & 42.5 & 18.3 & & 490 & 1.01 & 0.87 & 282 \\
\hline & 5.0 & 30.8 & 8.59 & 4.38 & 38.9 & 4.15 & 3.39 & 419 & 11.5 & 4.67 & 42.6 & 18.6 & & 489 & 1.01 & 0.87 & 269 \\
\hline & 10.0 & 30.5 & 8.58 & 4.30 & 39.0 & 4.15 & 3.41 & 417 & 11.5 & 4.70 & 42.5 & 18.5 & & 487 & 1.01 & 0.87 & 282 \\
\hline & 15.0 & 30.5 & 8.59 & 4.35 & 39.0 & 4.17 & 3.41 & 418 & 11.6 & 4.71 & 42.5 & 18.6 & & 488 & 1.02 & 0.88 & 275 \\
\hline & 20.5 & 30.5 & 8.56 & 4.34 & 39.1 & 4.20 & 3.47 & 422 & 11.5 & 4.73 & 42.8 & 18.6 & & 492 & 1.00 & 0.86 & 302 \\
\hline \multirow[t]{5}{*}{ June 1996} & 0.2 & 30.7 & 8.57 & 6.11 & 37.6 & 3.99 & 3.29 & 400 & 11.1 & 4.55 & 41.3 & 16.9 & & 470 & 0.98 & 0.84 & 282 \\
\hline & 5.0 & 30.5 & 8.58 & 6.15 & 37.5 & 4.00 & 3.29 & 402 & 11.0 & 4.58 & 41.3 & 17.0 & & 471 & 0.99 & 0.85 & 275 \\
\hline & 10.0 & 30.5 & 8.58 & 5.95 & 37.5 & 3.98 & 3.27 & 401 & 11.0 & 4.56 & 41.6 & 17.2 & & 471 & 0.99 & 0.85 & 269 \\
\hline & 15.0 & 30.9 & 8.53 & 6.09 & 38.8 & 4.14 & 3.45 & 422 & 11.3 & 4.70 & 42.8 & 19.2 & & 491 & 0.98 & 0.84 & 324 \\
\hline & 20.0 & 31.8 & 8.35 & 5.92 & 39.8 & 4.24 & 3.71 & 429 & 11.6 & 4.79 & 43.0 & 18.9 & & 499 & 0.88 & 0.74 & 575 \\
\hline
\end{tabular}

$\mathrm{SI}_{\mathrm{Cc}}, \mathrm{SI}_{\mathrm{Arag}}$ : Saturation index for calcite and aragonite, respectively. The lake level in June 1996 was $1 \mathrm{~m}$ higher
October 1983 were taken from Kempe and Kaźmierczak (1993) and have been recalculated for saturation indices.

October 1983 were taken from Kempe

a Redox intensity $\mathrm{p} \varepsilon=-\log \left\{\mathrm{e}^{-}\right\}$.
b Total alkalinity $=$acid-neutralizing

b Total alkalinity $=$ acid-neutralizing capacity expressed as milliequivalents per liter.

${ }^{c}$ Dissolved inorganic carbon DIC $=\left[\mathrm{CO}_{2}(\mathrm{aq})\right]+\left[\mathrm{H}_{2} \mathrm{CO}_{3}\right]+\left[\mathrm{HCO}_{3}{ }^{-}\right]+\left[\mathrm{CO}_{3}{ }^{2-}\right]$.

${ }^{\mathrm{d} S a t u r a t i o n}$ index $\mathrm{SI}=\log (\mathrm{IAP} / \mathrm{K})$, where IAP $=$ ion activity product of $\mathrm{Ca}^{2+}$ and $\mathrm{CO}_{3}{ }^{2-}$, and $\mathrm{K}=$ solubility product of calcite and aragonite, respectively

e Partial pressure of carbon dioxide.

${ }^{\mathrm{f}}$ Estimated.

We have shown by model calculation and occurrences of calcified cyanobacteria that cyanobacterial photosynthesis can induce $\mathrm{CaCO}_{3}$ precipitation to form distinct cyanobacterial microfossils only in settings of low DIC / high $\mathrm{Ca}^{2+}$ (Arp et al. 2001). For Lake Satonda the DIC is high enough to buffer the effect of cyanobacterial photosynthesis on $\mathrm{CaCO}_{3}$ supersaturation, which is consistent with results for other soda lakes (Arp et al. 2001). Therefore, photosynthesis appears not to be a significant factor in driving $\mathrm{CaCO}_{3}$ precipitation in Lake Satonda.

A further theoretical misconception of Kaźmierczak and Kempe is their assumption that anaerobic degradation and sulfate reduction must lead to higher supersaturation and $\mathrm{CaCO}_{3}$ precipitation. Our model calculations, however, have demonstrated that anaerobic exopolysaccharide decay via sulfate reduction lowers rather than raises supersaturation in Satonda biofilms.

\section{SUBFOSSIL STROMATOLITE-LIKE CRUSTS}

The subfossil stromatolite-like crusts on green algal filaments consist of fibrous aragonite and an amorphous $\mathrm{Mg}-\mathrm{Si}$ phase. Again, we have controlled our data by two further microprobe line measurements and two element mappings (Figs. 2A, B, 3, and supplementary data, see Acknowledgments) to exclude the possibility that we may have missed the crucial layers.

The ternary plot of $\mathrm{Ca}, \mathrm{Mg}$, and $\mathrm{Si}$ (calibrated concentrations; Fig. 2A) demonstrates that mixed signals of layers less than approximately $5 \mu \mathrm{m}$ thick form a continuous line, thereby maintaining constant $\mathrm{Mg}-\mathrm{Si}$ ratio, between aragonite and the amorphous $\mathrm{Mg}-\mathrm{Si}$ phase, distinct from $\mathrm{Mg}$ calcite. Two element mappings of stromatolitic crusts gave no other result (each mapping 250,000 data points, uncalibrated intensities; Fig. 2B and supplementary data, see Acknowledgements). The $\mathrm{Mg}-\mathrm{Si}$ relation is constant; there is no indication of $\mathrm{Mg}$-calcitic layers. $\mathrm{Mg}$-calcite (with low $\mathrm{Sr}$ ) has been detected only in the red alga Lithoporella, foraminiferal skeletons, and pellets in pockets between the stromatolitic crusts (Fig. 2A). Kaźmierczak and Kempe alter the results of our measurements (Arp et al. 2003, fig. 4) in an unacceptable way when stating that Satonda Lake stromatolitic crusts comprise "aragonitic layers alternating with calcitic layers (the latter often with some admixture of $\mathrm{SiO}_{2}$ or Mg-silicate)." We emphasize that there is neither indication of pure $\mathrm{SiO}_{2}$, nor of $\mathrm{Mg}$-silicate, nor a mixture of them with calcite (Figs. 2A, B, 3). What we found is aragonite and an amorphous $\mathrm{Mg}-\mathrm{Si}$ phase, which at best could be a precursor of a $\mathrm{Mg}$ silicate. This $\mathrm{Mg}-\mathrm{Si}$ phase is also characterized by high $\mathrm{Mn}$ concentrations
(Fig. 3), presumably due to the attraction to $\mathrm{OH}$ groups as would be the case for $\mathrm{Mg}$ in connection with $\mathrm{SiO}_{2}$ gels under slightly alkaline conditions. The Mn content may further substantiate our interpretation that the formation of the $\mathrm{Mg}-\mathrm{Si}$ phase is linked to mixing events and anoxic conditions (Arp et al. 2003). On the other hand, the aragonite layers are low in Mn (Fig. 3), demonstrating that aragonite growth did not take place under anaerobic conditions - in contrast to the theories of Kaźmierczak and Kempe.

Kaźmierczak and Kempe tried to demonstrate the Mg-calcitic mineralogy of the thin dark layers of the stromatolitic crusts by two EDX spectra and one single EDX map (their fig. 4A-C; Kempe and Kaźmierczak 1993, their plate 2/7-9). However, Kempe and Kaźmierczak (1993, plate 2/9) showed the $\mathrm{Mg}$ distribution (Fig. 4C) but not the $\mathrm{Ca}$ and $\mathrm{Si}$ distribution (i.e., biased presentation of data). These element maps would have shown that $\mathrm{Mg}$ correlates with $\mathrm{Si}$, excluding a Mg-calcitic mineralogy (Fig. 4D-G, and supplementary data, see Acknowledgments). In summary, Kaźmierczak and Kempe failed to provide any evidence for the presence of $\mathrm{Mg}$-calcitic layers in the subfossil microstromatolitic crusts.

\section{WETHEREDELLA-LIKE STRUCTURES}

Kaźmierczak and Kempe question our finding of resting bodies (gemmulae) in the Satonda sponge (Arp et al. 1996, their plate 2/6-7; Arp et al. 2003, their fig. 13C-D). However, such resting bodies are well described from a few marine sponges, especially from genera of the Suberitidae (Connes et al. 1978; Simpson 1984). The suberitid sponge from Satonda crater lake belongs to a new species of Protosuberites (former Laxosuberites sensu Topsent 1938, in Soest 2002). Protosuberites n.sp. is abundant in Satonda. Hardpart biofilm sections commonly show resting cysts in cavities and depressions located directly below living sponge basopinacoderm (Fig. $5 \mathrm{~A}-\mathrm{D})$. The resting cysts are subspherical structures with a collagenous wall attached to the substrate. The cells within the cystous structures are eukaryotic sponge cells because they show nuclei and compartmentation (Fig. 5E-F: archaeocytes and thesocytes). The suberitid cyst wall is singlelayered and lacks spicules (Connes et al. 1978; Simpson 1984). Only ultrastructural investigations show light and dark bands reflecting the density of microfibril arrangements, and, on the basis of the widths of these bands, an inner and an outer zone can be recognized in TEM sections (Connes et al. 1978; Simpson 1984). We have no TEM sections of Lake Satonda sponge cysts, but fluorescence microscopy of hardpart microtome sections also reveals a structural subdivision of the cyst walls in Satonda (Fig. 5D).

Kaźmierczak and Kempe simply did not observe the sponge resting bod- 

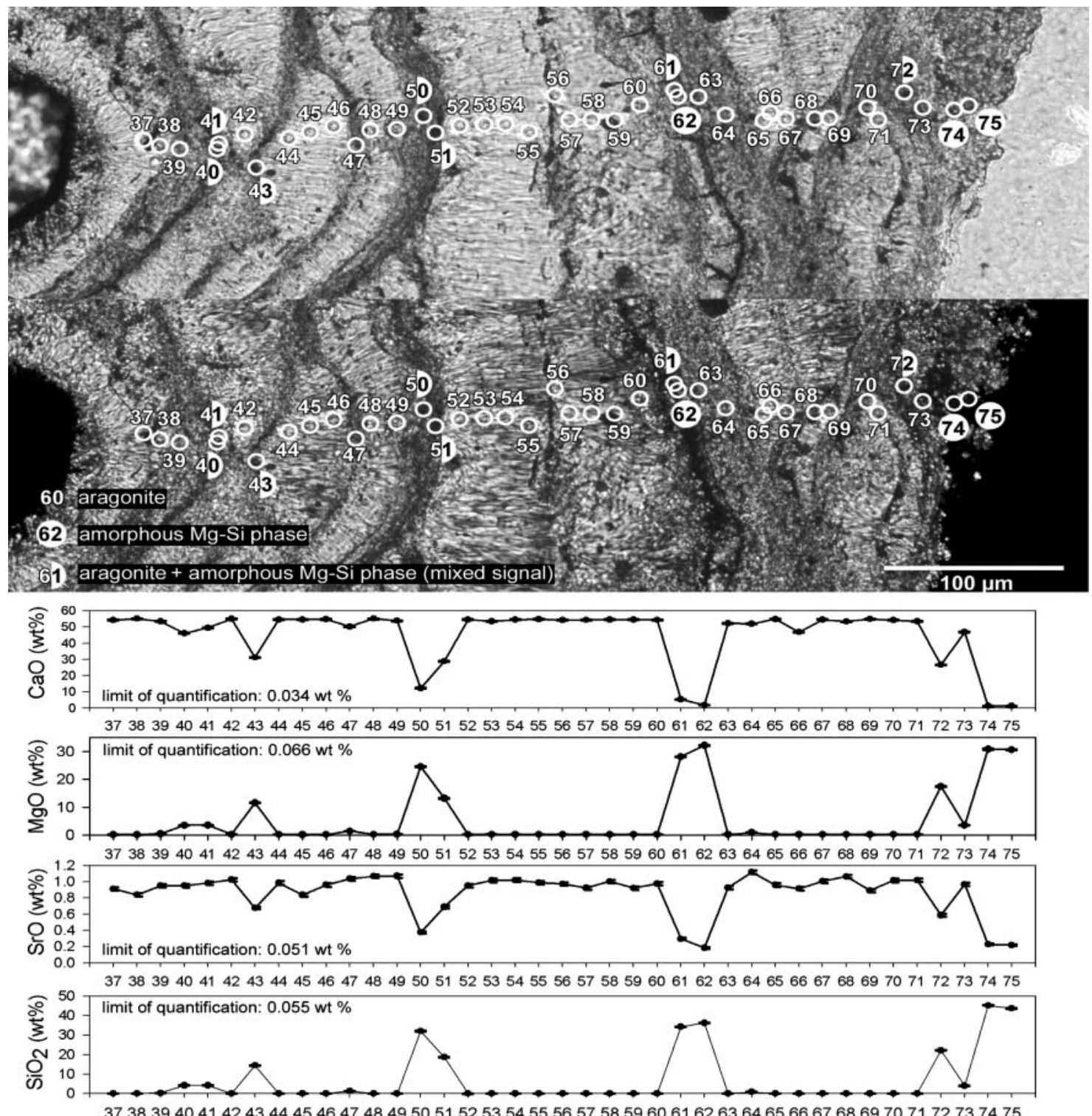

373839404142434445464748495051525354555657585960616263646566676869707172737475
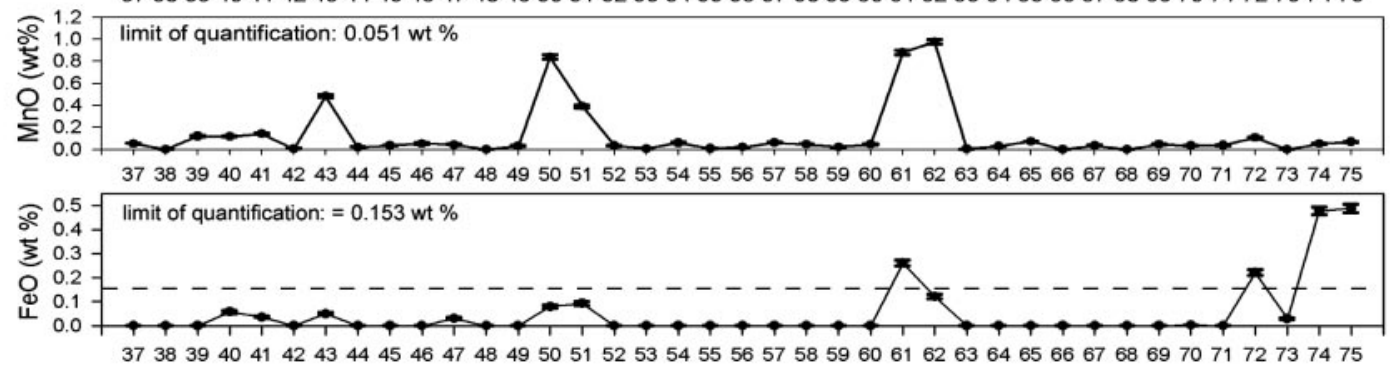

FIG. 3.-Electron microprobe traverse of a microstromatolitic crust of the subfossil reef core [Sample Sat 93/74 (1813)]. Transmitted light (upper micrograph) and crossed nicols (lower micrograph). Fibrous layers are composed of aragonite, whereas amorphous layers are composed of an unidentified $\mathrm{Mg}-\mathrm{Si}$ phase. Thin layers of microcrystalline appearance are formed by a mixture of aragonite and amorphous $\mathrm{Mg}-\mathrm{Si}$ phase (see Fig. 2). Note enrichment of $\mathrm{Mn}$ (and $\mathrm{Fe}$ ) in $\mathrm{Mg}-\mathrm{Si}$ layers, which are interpreted to have formed under anoxic conditions after seasonal upwelling of anoxic monimolimnion waters and overgrowth by fibrous aragonite.

ies because of inadequate sample treatment (air drying) and lack of biofilm sections. Furthermore, Kaźmierczak and Kempe have consequently ignored that the wall of subfossil Lake Satonda Wetheredella-like cysts is not composed of Mg-calcite or any other carbonate, but of amorphous material.

In addition to the above points, it has to be emphasized that the formation of a resistant outer sheath ("common glycocalix," Kaźmierczak and Kem- pe 1990, 1992) forming a cystous structure during degradation of coccoid cyanobacterial colonies has never been shown by any study investigating recent cyanobacterial biofilms. Furthermore, the unidirectional growth of aragonite fibers radiating from the base of the structures (Kaźmierczak and Kempe 1990, their fig. 4; Kaźmierczak and Kempe 1992, their fig. 7) is incompatible with decaying cyanobacterial sheath material providing uni- 

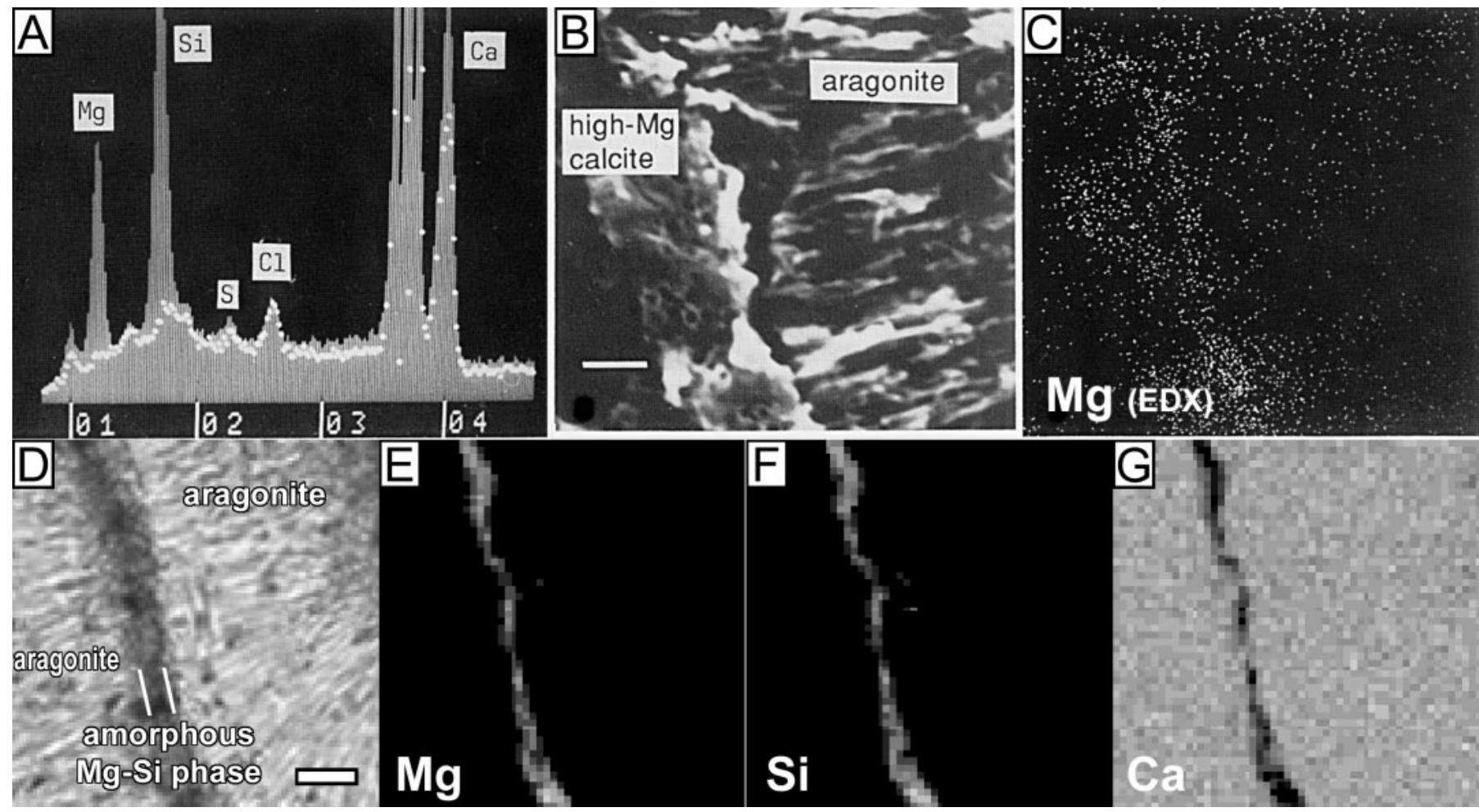

FIG. 4.-Comparison of EDX and WDX analyses of subfossil stromatolitic crusts, Satonda Crater Lake, Indonesia. A) From Kempe and Kaźmierczak (1993), who state "EDAX-spectra of the section [fig. $4 \mathrm{~B}$ ] showing the relative abundance of $\mathrm{Mg}, \mathrm{Si}, \mathrm{S}, \mathrm{Cl}$ and $\mathrm{Ca}$ in the aragonitic layer (dotted line) and in the high $\mathrm{Mg}$-calcitic layer (hatched curve). Note the high Mg concentration in the calcitic compared to the aragonitic layer."' B) From Kempe and Kaźmierczak (1993), who state "SEM view of cross-fractured and EDTA-etched fragment of the Satonda Crater Lake fossil calcareous stromatolite [...], showing the contact between the in vivo with high Mg calcite permineralized coccoid cyanobacterial layer and the post mortem with aragonite permineralized layer of decomposed coccoid cyanobacteria." Scale bar is $3 \mu \mathrm{m}$. C) From Kempe and Kaźmierczak (1993), who stated "EDAX-mapping of the same section showing magnesium distribution within both layers." Si and Ca distribution have not been shown. For scale see part B. D) Detail of an analogous section of subfossil microstromatolitic crust (thin section), which we have used for WDX element mapping. Our measurements demonstrate (see E-G) that $\mathrm{Mg}$ correlates with $\mathrm{Si}$ (amorphous $\mathrm{Mg}-\mathrm{Si}$ phase), whereas Ca forms a separate mineral phase (aragonite). Scale bar is 10 $\mu \mathrm{m}$. E) WDX element map of Mg. Same view as in part D. F) WDX element map of Si. Same view as in part D. G) WDX element map of Ca. Same view as in part D.

formly distributed nucleation sites. Why should no nucleation of $\mathrm{CaCO}_{3}$ occur at the supposed Mg-calcitic roof? Instead, hemispherical sponge cysts with collagenous walls poor in nucleation sites explain this observation (Arp et al. 2003). Here, the only place left for $\mathrm{CaCO}_{3}$ nucleation is at the base of the structure, allowing fan-like growth of aragonite fibers-as commonly observed in the Wetheredella-like structures of Satonda.

\section{PALEOZOIC STROMATOPOROIDS}

The comparison of Lake Satonda stromatolite-like crusts with Paleozoic stromatoporoids (Ordovician Cystostroma, Pseudostylodictyon, Clathrodictyon; Famennian Pseudolabechia, Stylostroma), and the conclusion that these stromatoporoids were built by calcifying coccoid cyanobacteria (i.e., some stromatoporoids are cyanobacterial stromatolites according to Kaźmierczak and Kempe 1990), is based on a highly interpretive, superficial comparison of schematic illustrations (e.g., Nestor 1964) and thin sections of subfossil Satonda reef carbonates. No valid argument to support the theory of "cyanobacterial stromatoporoids" (Kaźmierczak 1976) exists. Stromatoporoids, including the genera listed by Kaźmierczak and Kempe (1990), are coralline sponges (see Stearn 1975; Reitner 1992) and show mammelons (Cystostroma, Pseudostylodictyon, Stylostroma, Pseudolabechia), astrorhizae (Clathrodictyon), and pilae (see, e.g., Nestor 1964; Webby 1969; Kaźmierczak 1971; Stearn 1980). These characteristics do not occur in Lake Satonda stromatolite-like crusts or any other stromatolite.

Furthermore, no radial fibrous growth of carbonate crystals from the base of each cellular structure occurs, only a drusy mosaic of spar cements occurs in Paleozoic stromatoporoids (Webby 1969; Kaźmierczak 1971). Also, Paleozoic stromatoporoids have calcitic skeletons, whereas Satonda stromatolitic crusts are composed of aragonite and an amorphous $\mathrm{Mg}-\mathrm{Si}$ phase. We consider the "coccoid cyanobacterial structures" figured by Kempe and Kaźmierczak (1993, Plate 8/4) from aragonitic layers in Lake Satonda stromatolitic crusts to be artifacts, as described above.

\section{CONCLUDING REMARKS}

We hope that our paper and reply contributes some clarification to aspects of biofilm mineralization in general, and with regard to the case study of Satonda. We hope that the reader will focus on the validity of arguments presented above. In our opinion, the theory that certain "common enigmatic Paleozoic fossils" described as Wetheredella and stromatoporoids formed by calcifying coccoid cyanobacteria (Kaźmierczak and Kempe 1990) remains without evidence, ignores structural and mineralogical differences, and is not supported by Lake Satonda microbialites. Consequently, Paleozoic stromatoporoids themselves cannot serve as argument for elevated alkalinities in marine waters of that time. On the contrary, intensified calcification in many marine organisms during certain times in Earth history may rather reflect high $\mathrm{Ca}^{2+}$ concentrations (Stanley and Hardie 1998), which may or may not coincide with elevated levels of alkalinitites.

What we do not state is that our model of Lake Satonda microbialite formation will be the final solution. More knowledge is needed, especially with regard to the formation of the $\mathrm{Mg}-\mathrm{Si}$ phase. There is also a strong need for geomicrobiological investigations (in situ identification and lo- 


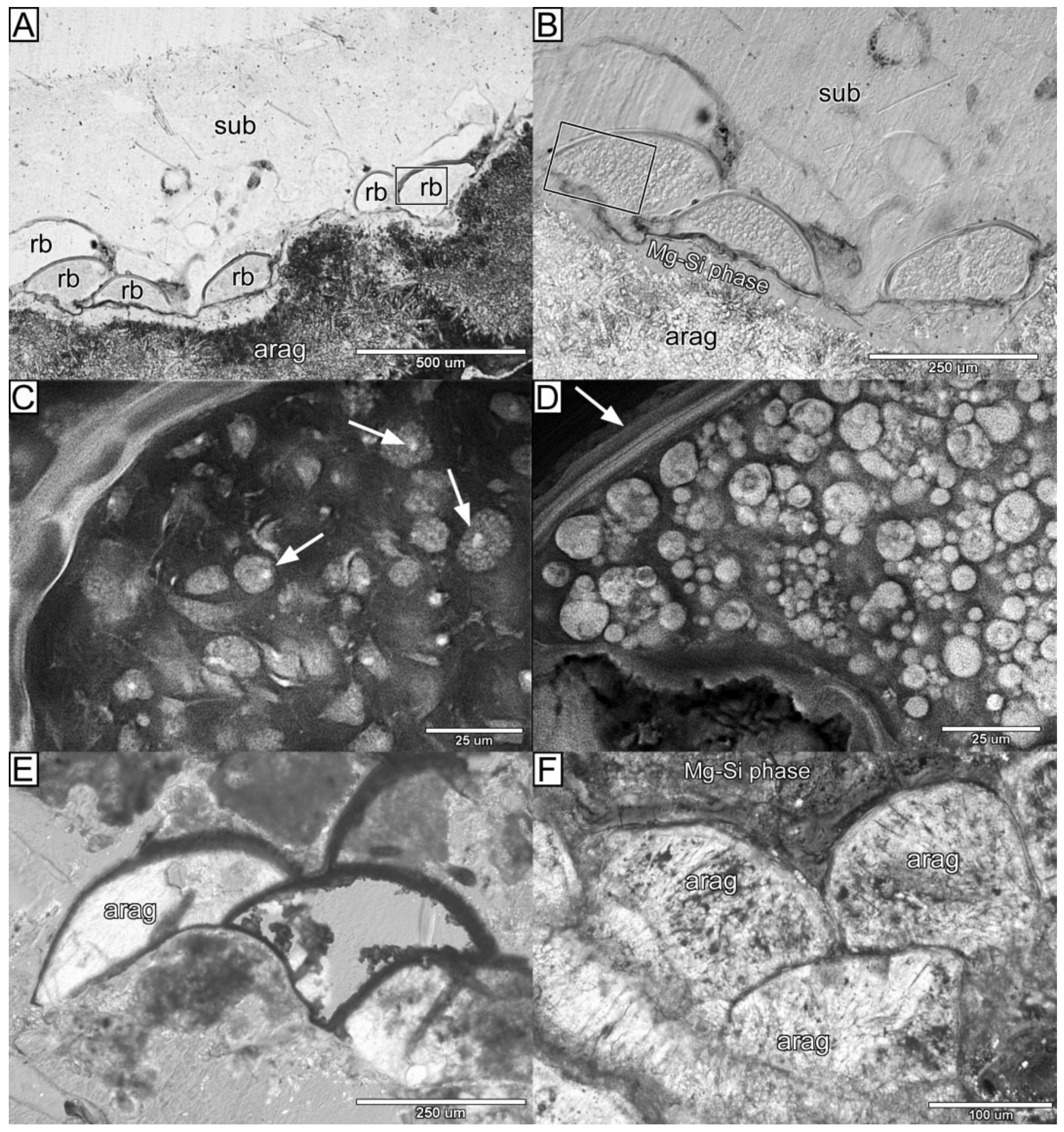

FIG. 5.-Recent hadromerid sponge resting bodies (gemmulae) and subfossil Wetheredella-like structures, Satonda Crater Lake, Indonesia. A) Overview of hadromerid sponge Protosuberites (sub) growing upon subfossil aragonitic reef carbonate (arag). Note subspherical resting bodies (rb), which are abundant at the base of sponge in Lake Satonda. Transmitted light. $18 \mathrm{~m}$ depth, reef \#10. Sample Sat 93/20. B) Detail from part A. Intergrowing subspherical gemmulae filled with sponge cells. The subfossil reef carbonate (arag) is veneered by an amorphous $\mathrm{Mg}-\mathrm{Si}$ layer $(\mathrm{Mg}-\mathrm{Si}$ phase). Nomarski optics. C) Detail from part A. Epifluorescence microscopy shows that in this case the resting body contains archeocytes prior to their transformation to thesocytes. Note compartmentation and nuclei (arrows) of the cells demonstrating their eukaryotic nature. The cyst wall is structurally subdivided into several layers. Deconvolved epifluorescence micrograph (ex 540-550 nm, em 565-595 nm). D) Detail from part B. Another resting body showing fully developed thesocytes with compartments. Note layered microstructure of the cyst wall (arrow). Deconvolved epifluorescence micrograph (ex 540-550 nm, em 565-595 nm). E) Intergrowing subfossil sponge cysts partially filled with fibrous aragonite (arag). $14 \mathrm{~m}$ depth, reef \#10. Nomarski optics. Sample Sat 93/69. F) Subfossil Wetheredella-like structures filled with fibrous aragonite (arag). These Wetheredella-like structures occur in partially silicified (Mg-Si phase) peloidrich pocket of red-algal reef framework. Usually, the cyst walls are also silicified by the $\mathrm{Mg}-\mathrm{Si}$ phase. $0.5 \mathrm{~m}$ depth, reef \#1. Plane polarized light. Sample Sat $93-68$. 
cation of bacteria, tracing their physiological activity, etc.). In any case, progress is dependent on the ability to modify, revise, or reject past models when they turn out to be incompatible with new data and observations.

\section{ACKNOWLEDGMENTS}

We thank Andreas Kronz (GZG, Geochemistry, University of Göttingen) for electron microprobe analysis and discussion of data. Discussions with Martin Dietzel (Institute of Engineering Geology and Applied Mineralogy, University Graz), and Thomas Friedl (Culture Collection of Algae at the University of Göttingen) helped with regard to mineralogy and identification of algae, respectively. Thanks to David Budd and John B. Southard for lingual improvements.

The supplementary data described in this paper have been archived, and are available in digital form, at the World Data Center for Marine Geology and Geophysics, NOAA/NGDC E/GC3, 325 Broadway, Boulder, CO 80303; (Phone: 303-497-6339; fax: 303-497-6513; E-Mail: wdcmgg@ngdc.noaa.gov; URL: http//www.ngdc.noaa. gov/mgg/sepm/archive/index.html)

\section{REFERENCES}

Arp, G., Reitner, J., Wörheide, G., and Landmann, G., 1996, New data on microbial communities and related sponge fauna from the alkaline Satonda Crater Lake (Sumbawa, Indonesia), in Reitner, J., Neuweiler, F., and Gunkel, F., eds., Global and Regional Controls on Biogenic Sedimentation. I. Reef Evolution, Research Reports: Göttinger Arbeiten zur Geologie und Paläontologie, Sonderband 2, p. 1-7.

Arp, G., Reimer, A., And Reitner, J., 1999, Calcification in cyanobacterial biofilms of alkaline salt lakes: European Journal of Phycology, v. 34, p. 393-403.

Arp, G., Reimer, A., And Reitner, J., 2001, Photosynthesis-induced biofilm calcification and calcium concentrations in Phanerozoic oceans: Science, v. 292, p. 1701-1704.

Arp, G., Reimer, A., and Reitner, J., 2003, Microbialite formation in seawater of increased alkalinity, Satonda Crater Lake, Indonesia: Journal of Sedimentary Research, v. 73, p. 105127.

Burne, R.V., AND Moore, L.S., 1987, Microbialites: Organosedimentary deposits of benthic microbial communities: Palaios, v. 2, p. 241-254.

Chou, H.M., AND Huang, T.C., 1991, Ultrastructure of the aerobic, nitrogen-fixing unicellular cyanobacterium Synechococcus sp. RF-1: Archiv für Hydrobiologie, Supplementband, v. 92 ( = Algological Studies, v. 64), p. 53-59.

Connes, R., Carrière, D., And Paris, J., 1978, Étude du developpement des gemmules chez la demosponge marine Suberites domuncula (Olivi) Nardo: Annales des Sciences Naturelles, Zoologie, Paris, v. 20, p. 357-387.

Craig, H., 1953, The geochemistry of stable carbon isotopes: Geochimica et Cosmochimica Acta, v. 3, p. 53-92.

Dupraz, C., AND ReID, R.P., 2001, Early carbonate precipitation in microbial mats: Hypersaline lakes, Bahama: $21^{\text {st }}$ International Association of Sedimentologists Meeting of Sedimentology, 3-5 September 2001, Davos, Switzerland, Abstracts and Programme, p. 175.

FENCHEL, T., AND KüHL, M., 2000, Artificial cyanobacterial mats: growth, structure, and vertical zonation pattern: Microbial Ecology, v. 40, p. 85-93.

Hofmann, H.J., 1973, Stromatolites: characteristics and utility: Earth-Science Reviews, v. 9, p. $339-373$.

Jørgensen, B.B., Revsbech, N.P., And Cohen, Y., 1983, Photosynthesis and structure of benthic microbial mats: Microelectrode and SEM studies of four cyanobacterial communities: Limnology and Oceanography, v. 28, p. 1075-1093.

KaźmierCZAK, J., 1971, Morphogenesis and systematics of the Devonian stromatoporoidea from the Holy Cross Mountains, Poland: Palaeontologia Polonica, v. 26, p. 1-150, pls. 1-41.

KAŹMIERCZAK, J., 1976, Cyanophycean nature of stromatoporoids: Nature, v. 264, p. 49-51.

KaźmierczaK, J., and Kempe, S., 1990, Modern cyanobacterial analogs of Paleozoic stromatoporoids: Science, v. 250, p. 1244-1248.

KAźmierCZAK, J., and Kempe, S., 1992, Recent cyanobacterial counterparts of Paleozoic Wetheredella and related problematic fossils: Palaios, v. 7, p. 294-304.
Kaźmierczak, J., Lacka, B., Malkowski, K., Kempe, S., Kulicki, C., and Kuzniarski, M., 2001, Calcification potential of artificial marine cyanobacterial mats, in Krumbein, W.E., Dornieden, T., and Volkmann, M., eds., A Symposium on Fossil and Recent Biofilms: Oldenburg, February 16-22, 2001, Programme, Abstracts and Participants, loosely attached page.

KEMPE, S., 1990, Alkalinity: the link between anaerobic basins and shallow water carbonates?: Naturwissenschaften v. 77 , p. 426-427.

Kempe, S., and KaźmierczaK, J., 1990a, Calcium carbonate supersaturation and the formation of in situ calcified stromatolites, in Ittekkot, V.A., Kempe, S., Michaelis, W., and Spitzy, A., eds., Facets of Modern Biogeochemistry: Berlin, Springer-Verlag, p. 255-278.

Kempe, S., and KaźmierczaK, J., 1990b, Chemistry and stromatolites of the sea-linked Satonda Crater Lake, Indonesia: A recent model for the Precambrian sea?: Chemical Geology, v. 81, p. 299-310.

Kempe, S., and KaźmierczaK, J., 1993, Satonda Crater Lake, Indonesia: Hydrogeochemistry and Bicarbonates: Facies, v. 28, p. 1-32.

Kempe, S., Kaźmierczak, J., Reimer, A., Landmann, G., and Reitner, J., 1996, Microbialites and hydrochemistry of the Crater Lake of Satonda-a status report, in Reitner, J., Neuweiler, F., and Gunkel, F., eds., Global and Regional Controls on Biogenic Sedimentation. I. Reef Evolution. Research Reports: Göttinger Arbeiten zur Geologie und Paläontologie, Sonderband 2, p. 59-63.

Kempe, S., Kaźmierczak, J., Reimer, A., Landmann, G., and Reitner, J., 1997, Satonda: a porthole view into the oceanic past, in Tomascik, T., Mah, A.J., Nontji, A., and Moosa, M.K., eds., The Ecology of Indonesian Seas: Jakarta, Periplus Editions, p. 156-166.

KenNARD, J.M., AND JAMES, N.P., 1986, Thrombolites and stromatolites: two distinct types of microbial structures: Palaios, v. 1, p. 492-503.

KомÁREK, J., 1999, Intergeneric characters in unicellular cyanobacteria, living in solitary cells: Archiv für Hydrobiologie, Supplementband, v. 129 ( = Algological Studies, v. 94), p. 195205 .

KomÁREK, J., AND ČÁSLAVSKÁ, J., 1991, Thylakoid patterns in oscillatorialean cyanophytes: Archiv für Hydrobiologie, Supplementband, v. 92 ( = Algological Studies, v. 64), p. 267 270 .

Krumbein, W.E., Cohen, Y., And Shilo, M., 1977, Solar Lake (Sinai). 4. Stromatolitic cyanobacterial mats: Limnology and Oceanography, v. 22, p. 635-656.

KüHl, M., Fenchel, T., AND KaźmierczaK, J., 2003, Structure, function, and calcification potential of an artificial cyanobacterial mat, in Krumbein, W.E., Paterson, D., and Zavarzin, G., eds., Fossil and Recent Biofilms-A Natural History of the Impact of Life on Planet Earth: Dordrecht, The Netherlands, Kluwer Academic Publishers, p. 77-102.

Nestor, H.E., 1964, Stromatoporoidei ordovika i llandoveri Estonii: Eesti NSV Teaduste Akadeemia Geoloogia Instituut, Tallinn, p. 1-111.

Paerl, H.W., StepPe, T.F., and Reid, R.P., 2001, Bacterially mediated precipitation in marine stromatolites: Environmental Microbiology, v. 3, p. 123-130.

ReITNER, J., 1992, Coralline Spongien. Der Versuch einer phylogenetisch-taxonomischen Analyse: Berliner Geowissenschaftliche Abhandlungen, series E, v. 1, p. 1-352.

Simpson, T., 1984, The Cell Biology of Sponges: New York, Springer, 662 p.

Stanley, S.M., AND Hardie, L.A., 1998, Secular oscillations in the carbonate mineralogy of reef-building and sediment-producing organisms driven by tectonically forced shifts in seawater chemistry: Palaeogeography, Palaeoclimatology, Palaeoecology, v. 144, p. 3-19.

StEARN, C.W., 1975, The stromatoporoid animal: Lethaia, v. 8, p. 89-100.

Stearn, C.W., 1980, Classification of the Paleozoic stromatoporoids: Journal of Paleontology, v. 54, p. $881-902$

Soest, van, R.W.M., 2002, Family Suberitidae Schmidt, 1870, in Hooper, J.N.A., and Soest van, R.W.M., eds., Systema Porifera: Dordrecht, The Netherlands, Kluwer Academic Publishers, v. 1, p. 227-244.

Stevens, S.E., JR., and Nierzwicki-Bauer, S.A., 1991, The Cyanobacteria, in Stolz, J.F., ed. Structure of Phototrophic Prokaryotes: Boca Raton, Florida, CRC Press, p. 15-47.

Topsent, E., 1938, Commentaires sur quelques genres d'eponges marines: Institut Océanographique, Monaco, Bulletin, v. 744, p. 1-23.

WALTER, M.R., 1983, Archean stromatolites: evidence of the Earth's earliest benthos, in Schopf, J.W., ed, Earth's Earliest Biosphere: Princeton, New Jersey, Princeton University Press, p. 187-213.

WeBBy, B.D., 1969, Ordovician stromatoporoids from New South Wales: Palaeontology, v. 12, p. 637-662.

Received 10 August 2003; accepted 15 August 2003. 